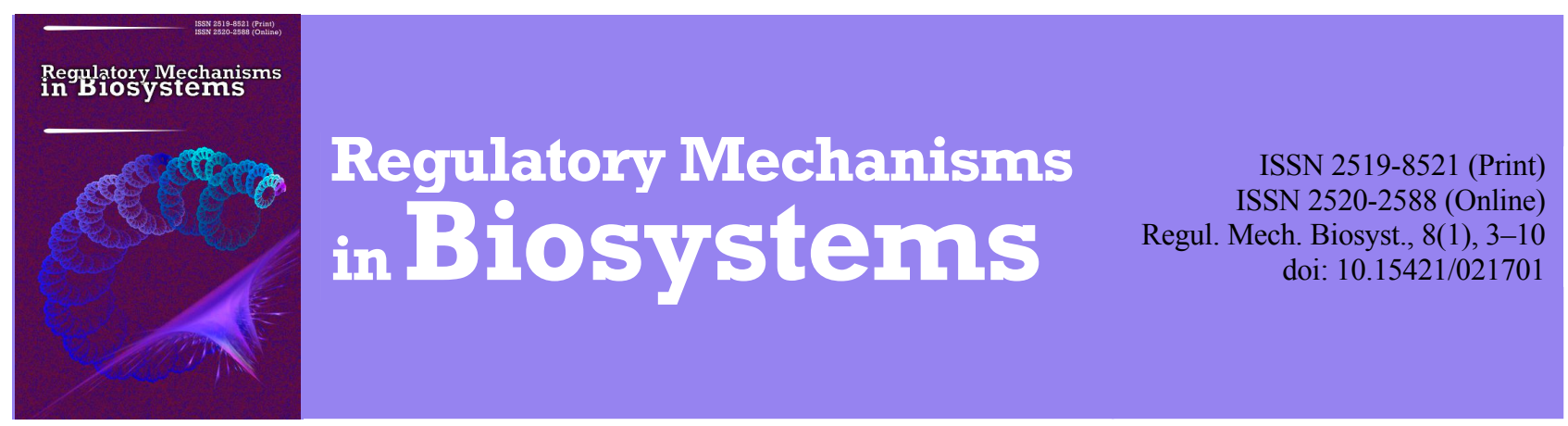

\title{
Borna disease virus and its role in the pathology of animals and humans
}

\author{
A. O. Mikheev \\ Bukovinian State Medical University, Chernivtsi, Ukraine
}

Article info

Received 14.12.2016

Received in revised form 25.12.2016

Accepted 28.12.2016

Bukovinian State Medical University, Theatralna sq., 2 Chernivtsi, 58002, Ukraine Tel.: +38-099-631-04-11 E-mail:maos@bsmu.edu.ua Mikheev, A. O. (2017). Borna disease virus and its role in the pathology of animals and humans. Regulatory
Mechanisms in Biosystems, 8(1), 3-10. doi: 10.15421/021701

Infectious diseases that are caused by numerous pathogenic microorganisms - bacteria, viruses, protozoa or fungi can be transmitted from patients or carriers to healthy people or animals. A large group of infectious disease is caused by pathogens of animal infections - zoonoses. The issue of zoonoses is of great significance in human pathology and requires comprehensive study. This is of particular relevance to Ukraine, as the question of prevalence, level within the population and threats to human life and health from zoonoses, though highly important, has remained insufficiently studied. Information about many of these pathogens is absent in the existing scientific literature accessible in Ukraine both veterinary and medical. This applies, in particular, to a causative agent of viral zoonoses the Borna disease virus or Bornavirus. For this purpose, an analysis of the literature concerning the role of the Bornavirus in the pathology of animals and humans was conducted. It is well known that a large number of pathogens of animal infections (zoonoses), including viral, pose a potential threat to human health. Among these potential threats is the Borna disease virus belonging to the family of Bornaviridae, order Mononegavirales. This order includes representatives of deadly human diseases like rabies (family Rhabdoviridae), Ebola virus (family Filoviridae) and Nipah virus (family Paramyxoviridae). Borna virus disease affects mainly mammals, but can infect birds and even reptiles (Aspid bornavirus). It is established that Bornaviruses have a wide range of natural hosts (horses, sheeps, cats, bats and various birds), including domestic animals, which poses a potential threat to human health. This is evidenced by numerous, although contradictory, research into the role of the Borna disease virus in human pathologies such as schizophrenia, depression, prolonged fatigue syndrome, multiple sclerosis and others. Analysis of the literature clearly shows the important role of the Borna disease virus in a variety of mental and behavioural changes in animals, both wild and domestic. However, the large amount of contradictory data and studies cannot yet provide a clear picture of the role of this virus in human pathology. On the one hand, there are clear data of the presence of RNA of the Bourna disease virus and antibodies to it in patients with psychoneurotic changes. On the other, there is no clear understanding of the infectivity of the virus in humans and its transmission from animals to humans and from person to person. These questions require further research and comprehensive study, particularly on the territory of Ukraine.

Keywords: zoonoses; infectious diseases; Bornaviruses; diseases of humans and animals

\section{Вірус хвороби Борна та його значення в патології тварин і людини}

\author{
A. О. Мiхєєв
}

\section{Буковинський державний медичний університет, Чернівиі, Украӥна}

Проведено аналіз літературних джерел, які стосуються ролі вірусу Борна у патології тварин і людини. Велика кількість збудників тваринних інфекцій (зоонозів), зокрема, вірусних, становить потенційну загрозу здоров'ю людини. Серед таких потенційних загроз - вірус хвороби Борна, що належить до родини Bornaviridae, порядку Mononegavirales. До цього порядку входять представники таких смертельних для людини захворювань як сказ (родина Rhabdoviridae), вірус Ебола (родина Filoviridae), вipyc Нiпах (родина Рaramyхоviridae). Bipyc хвороби Борна вражає переважно ссавців, проте може вражати птахів і навіть плазунів (борнавірус аспідових). Борнавіруси мають велике коло природних господарів (коні, вівці, котячі, кажани, гризуни, комахоїдні, різноманітні птахи), у тому числі серед домашніх тварин, уражають переважно нервову систему з розвитком безсимптомного носійства або менінгоенцефалітів, енцефалітів, поведінковими розладами тощо. А це може являти потенційну загрозу здоров’ю людини. Про це свідчать численні, хоча і суперечливі, дослідження стосовно ролі вірусу хвороби Борна у таких патологіях людини як шизофренія, депресія, синдром тривалої втоми, розсіяний склероз тощо. Проаналізувавши велику кількість літературних джерел, можна підтвердити суттєву роль вірусу хвороби Борна у патології людини та тварин, проте в Україні питання стосовно його поширення, циркуляції та патогенності практично не розглядається. Тому важливі подальші дослідження поширеності цього вірусу серед диких і домашніх тварин, установлення його значення у патології людини.

Ключові слова: борнавіруси; зоонози; інфекційні захворювання; патологія людини 


\section{Вступ}

Інфекційні захворювання, які викликають численні патогенні мікроорганізми (бактерії, віруси, найпростіші або гриби), здатні передаватися від хворих або носіїв до здорових людей чи тварин. Велику групу таких інфекційних захворювань складають збудники тваринних інфекцій - зоонози (Gorohov et al., 2012). У медицині та ветеринарії зоонози, у тому числі вірусної природи, традиційно належали до інфекцій, що притаманні тільки тваринам (Sidorchuk, 2014). Серед них велика група транскордонних емерджентних інфекцій, що є досить екзотичним для України: віруси лихоманки Західного Нілу, атипової пневмонії, пташиного $\left(\mathrm{H}_{5}\right)$ та свинячого $\left(\mathrm{H}_{1}\right)$ грипу, хвороби Борна, Ебола, Марбург, Ласса, Ніпах та інші (Bisjuk, 2014). Однак багато 3 них мають здатність до міжвидової передачі від птахів до ссавців і навпаки, та, нарешті, від тварин або птахів до людини, тобто зооантропонози (Grynevych and Markovych, 2012; Markovych and Grynevych, 2013; Christou, 2011; Wang and Crameri, 2014). Зокрема, це також представники різноманітних родин вірусів - Poxviridae, Flaviviridae, Filoviridae, Reoviridae, Bornaviridae, Picobirnaviridae. Останніми роками список таких захворювань суттєво розширився, а спалахи, що раніше мали локальний характер, переростають в епідемії (Grynevych et al., 2012). Причина цього - розширення території проживання людини, урбанізація, наявність достатньо великої кількості синантропних тварин, птахів і комах (пацюки, летючі миші, голуби, таргани), які $є$ природними джерелами та резервуарами таких інфекцій (Stegnij et al., 2014; Rosenberg, 2015). Спрогнозувати епідемію, спричинену збудниками вірусних зоонозів серед людей, складно, а часто неможливо (Dacheux et al., 2014; Makarov, 2011; Hasnatinov and Danchinova, 2011). Адже не всі збудники зоонозних інфекцій - «класичні» зоонози, багато 3 них здатні адаптуватися до нових господарів, у тому числі людини. Особливо це стосується тих патогенів, які мають широке коло тваринних господарів і досить тривалий інкубаційний період (Tеmmam et al., 2014).

Питання зоонозів, зокрема, вірусних, та їх значення в патології людини актуальне та потребує всебічного вивчення. Адже останніми роками це стало серйозною проблемою охорони здоров'я, оскільки близько 60-80\% нових вірусних інфекцій людини мають саме тваринне походження (Wang and Crameri, 2014). Зокрема, це стосується України, оскільки питання поширеності, популяційного рівня та загрози життю та здоров'ю людини стосовно зоонозів, особливо вірусних, вивчене недостатньо. Часто у доступній літературі міститься досить мало відомостей про природні резервуари збудників зоонозних інфекцій та їх епідеміологію, а повноцінна інформація про деякі з таких збудників взагалі відсутня в наявній науковій літературі України - як ветеринарній (Fotin et al., 2010), так і біологічній та медичній. Зокрема, це стосується таких збудників вірусних зоонозів як віруси хвороби Борна, або борнавіруси. Водночас у світі це питання обговорюється досить давно і з різних точок зору - від значення вірусів, у тому числі борнавірусів, в еволюції до розвитку психічних розладів у людини. Мета цього огляду літератури - з'ясувати значення вірусу хвороби Борна в захворюваннях тварин i людини, зокрема, в Україні.

\section{Загальні відомості про родину Bornaviridae}

Вірус хвороби Борна, борнавірус (Bornavirus, Borna disease virus (BDV)) - типовий представник родини Борнавіруси (Bornaviridae), що належить до порядку Mononegavirales (Kalinina, 2014). Віріони вірусів мають сферичну форму, розміром до 130 нм діаметром, спірального типу симетрії. Як генетичний матеріал вірус містить односпіральну лінійну РНК, несегментовану, 3 негативною полярністю. Геном має певну подібність до геному іншого представника порядку - родини Рабдовіруси (Rabdoviridae). Транскрипція та реплікація борнавірусів відбу- вається винятково в ядрі зараженої клітини, що відрізняє його від більшості інших РНК-вмісних вірусів та свідчить про досить давнє походження. У процесі реплікації вірус вмонтовує ДНК копії свого геному в ДНК клітини господаря, які під час мітотичного поділу передаються дочірнім клітинам (Matsumoto et al., 2012). Це, можливо, сприяє формуванню повільно прогресуючої або хронічної інфекції. Проникають борнавіруси у клітину хазяїна шляхом рецепторно опосередкованого ендоцитозу, а залишають інфіковану клітину шляхом брунькування через ЦПМ у сусідню клітину. Здатні поширюватися по міжклітинних зв'язках. Часто при цьому віруси не проявляють цитопатичного ефекту та не порушують нормального функціонування клітин.

Антигенні властивості борнавірусів представлені декількома детермінантами (білками), які кодуються в РНК. Це розчинний антиген (s-антиген), який містить білки нуклеопротеїн $\mathrm{N}$ (p40), фосфопротеїн $\mathrm{P}$ (p24), мембранний глікопротеїн $\mathrm{M}$ (gp18), мембранний глікопротеїн G (gp94), полімеразу L (p190) та X протеїн (p10), функції якого ще не з'ясовані, серед яких найбільше значення у діагностиці захворювань, спричинених борнавірусами, мають р40 та p24 (de la Torre, 1994; Ikuta et al., 2002; Bode and Ludwig, 2003). В організмі тварин i, можливо, людини ці детермінанти викликають відповідну імунну відповідь, а антитіла до борнавірусів залежать від виду ураженого організму та проявляють перехресну реактивність.

Борнавіруси досить стійкі у зовнішньому середовищі. Вони здатні залишатися інфекційними за низьких температур упродовж року, близько тижня за кімнатної температури, стійкі до висушування, але чутливі до ультрафіолету та низьких значень рH (Planz et al., 1999).

У лабораторних умовах вдається культивувати вірус у культурах клітин ембріонального походження (тканина нирок або ЦНС ембріона людини, гліальні клітини кроля), а також Vero, MDCK, гліома щурів.

Згідно з міжнародною класифікацією, за даними Міжнародного комітету з таксономії вірусів (ICTV), до родини Борнавіруси (Bornaviridae) належить один рід, в якому 7 основних видів борнавірусів:

- Elapid 1 bornavirus (зміїний борнавірус, вірус уражає представників родини Аспідові (Elapidae);

- Mammalian 1 bornavirus (типовий представник, уражає представників класу Ссавці (Mammalia), основний збудник хвороби Борна);

- Passeriform 1 bornavirus (пташиний борнавірус, уражає різних представників ряду Горобцеподібні (Passeriformes);

- Passeriform 2 bornavirus (пташиний борнавірус, уражає різних представників ряду Горобцеподібні (Passeriformes);

- Psittaciform 1 bornavirus (пташиний борнавірус, уражає різних представників ряду Папугоподібні (Psittaciformes);

- Psittaciform 2 bornavirus (пташиний борнавірус, уражає різних представників ряду Папугоподібні (Psittaciformes);

- Waterbird 1 bornavirus (пташиний борнавірус, уражає різні види водоплавних птахів) (Kuhn et al., 2015; Afonso et al., 2016).

\section{Біологічні особливості борнавірусів}

Вірус хвороби Борна - специфічний вірус, із високою тропністю до нервової системи, який переважно вражає тварин (зоонозна інфекція) (Kinnunen et al., 2013). Природними господарями борнавірусів вважаються коні та вівці, у яких ці віруси викликають чіткі неврологічні ураження - енцефаліти, енцефаломієліти, що часто закінчуються загибеллю тварин (Richt et al., 1997; Ludwig and Bode, 2000; Tizard et al., 2016). Окрім коней і овець вірус здатний інфікувати досить широкий спектр інших теплокровних тварин, має специфічний цикл реплікації, що спричиняє порушення сигнальних шляхів у ЦНС із виникненням невропатії, ураженням лімбічної системи (Bonnaud et al., 2015; Liu et al., 2015; Lennartz et al., 2016). Залежно від віку та виду господаря, іноді статі та часу зара- 
ження, а також особливостей імунної системи вірусна хвороба Борна може перебігати як безсимптомно (Lundgren et al., 1993; Richt and Rott, 2001), так і спричиняти широкий спектр поведінкових розладів (Staeheli et al., 2000; de la Torre, 2002; Hornig et al., 2003).

Із того часу, як було встановлено, що ВХБ викликає захворювання ЦНС у багатьох видів хребетних, він став моделлю для вивчення персистенції вірусної інфекції ЦНС, оскільки його одноланцюгова РНК реплікується в ядрі клітин-мішеней (Feschotte, 2010; Horie et al., 2010). Борнавіруси здатні вражати безпосередньо нейрони, астроцити, клітини глії, а також окрім клітин ЦНС може бути виявлений у клітинах периферійної нервової системи, крові, вилочкової залози та кісткового мозку (Carbone, 2001). Він здатен вмонтовувати свій генетичний матеріал у геном хазяїна та змінювати його. Це також призводить до тяжких, часто смертельних, енцефалітів у чутливих видів тварин, може викликати стійке захворювання неврологічного характеру, пов'язане з різними поведінковими змінами, а також ретиніти та сліпоту (Tizard et al., 2016; Wensman et al., 2016). Хоча міжвидова передача цього вірусу остаточно не доведена, слід мати на увазі, що він може бути й зооантропонозом (Bode and Ludwig, 2003; Brnic et al., 2011).

Як основні можливі шляхи передачі вірусу більшість авторів вказує повітряно-крапельний, контактний, особливо через різноманітні ушкодження шкірних покривів, різні виділення (фекалії та сеча тварин, аліментарний, а також вертикальний) (Carbone, 2001; Okamoto et al., 2003; Kerski et al., 2012). He доведеною залишається можливість прямої передачі борнавірусів від тварин до людини при догляді, полюванні, вирощуванні на фермах чи утримуванні вдома.

\section{Екологія та поширення борнавірусів}

Оскільки природні господарі борнавірусів - коні та вівці, географічне поширення хвороби Борна тривалий час було невідомим або прив'язаним до ареалів поширення саме цих тварин (Hatalski et al., 1997). Як природна інфекція цей вірус зареєстрований у Центральній Європі, Північній Америці, Азії (Японія, Ізраїль). Таке географічне обмеження, можливо, було наслідком відсутності надійного методу та тест-систем для постановки діагнозу інфекції або відмови розглядати вірус Борна як можливий збудник інфекції тварин або навіть людини.

Водночас недавні численні повідомлення про можливість безсимптомного природного носійства у тварин свідчать, що вірус, можливо, навіть набагато ширше поширений, ніж вважалося. Вірус хвороби Борна (ВХБ) розповсюджений по всьому світі, вражає переважно диких і домашніх тварин - кролів, коней, овець, собак, лисиць, єнотів і навіть страусів (Kinnunen et al., 2013; Lutz et al., 2015; Kuhn et al., 2015; Bourg et al., 2016).

У природних умовах захворювання встановлене також у великої рогатої худоби та кішок (Caplazi et al., 1994; Lundgren et al., 1995; Lutz et al., 2015). В останніх спостерігається явище спонтанного негнійного енцефаломісліту, порушення ходи («хитка хвороба»), зміни у поведінці, втрата нюху. При цьому ризик заразитися в котів у сільській місцевості набагато вищий, ніж у міській. Це, очевидно, пов'язано 3 великою кількістю різноманітних дрібних гризунів. Крім того, автори як можливий фактор поширення та передачі борнавірусів у даному випадку розглядають кліщів, які паразитують на землерийках та інших комахоїдних. Основні прояви ВХБ у великої рогатої худоби важкий прогресуючий розлад ЦНС із виявленням вірусу в нейронах головного мозку тварин та високим титром антитіл у сироватці крові. Як вказують самі автори, це був випадок природного інфікування тварин (Caplazi et al., 1994).

В експериментальних умовах до вірусу також чутливі багато різних тварин: від птахів до гризунів та приматів (Stitz et al., 1980; Dittrich et al., 1989; Berg et al., 2001). Серед можливих представників диких птахів як природний резервуар автори вказують диких качок або крижнів (Anas platyrhynchos) і галок
(Corvus monedula). У лабораторних щурів за умов експериментального зараження вірусом хвороби Борна спостерігали істотне зниження здатності до навчання у лабіринті, уникати біль, зміну поведінки. За внутрішньомозкового інфікування в лабораторних умовах макак-резусів суспензією мозку кролів, яка містила борнавірус, у тварин спостерігали ознаки енцефаломієліту та ретинопатію. Це підтверджувалося за допомогою імуноелектрофорезу з виявленням вірусспецифічних антитіл у сироватці крові та спинномозковій рідині піддослідних тварин. У природі різні птахи (горобці, папуги, чайки, голуби, водоплавні птахи)природні резервуари, вони самі можуть хворіти пташиними видами борнавірусів (Passeriform, Psittaciform i Waterbird bornavirus) із розвитком енцефаломієліту (Staeheli et al., 2010). Крім ураження ЦНС (лімфоцитарний енцефаліт) у птахів, зокрема, з ряду Папугоподібні, може спостерігатися ураження шлунково-кишкового тракту, порушення травлення, i, як наслідок, виснаження, втрата апетиту та ваги, часто з летальним завершенням. А часто незаконна торгівля різними видами цих птахів спричинює неконтрольоване поширення інфекції серед інших видів, у тому числі домашньої птиці (Berg et al., 2001). Серед представників ряду Папугоподібні встановлено можливість вертикальної передачі борнавірусів від заражених батьків до потомства (Kerski et al., 2012). Це підтверджено виявленням РНК пташиного борнавірусу в головному мозку, сироватці крові та пір”ї як у батьків, так і потомства.

Нещодавні дослідження також показали здатність вірусу Борна циркулювати серед представників рукокрилих та комахоїдних - кажанів та білочеревих білозубок (Dacheux et al., 2014; Dürrwald, 2014). Оскільки кажани - природний резервуар багатьох вірусних інфекцій, вони часто перебувають у тісному контакті з людиною. Дослідження популяцій комахоїдних кажанів у Франції показало наявність у їх організмі представників багатьох родин вірусів, у тому числі борнавірусів. Тому дослідники зробили висновок про значну роль цих тварин у поширенні зоонозних вірусних інфекцій. Водночас, білочереві білозубки виявилися одним із потенційних резервуарів борнавірусів в ендемічних регіонах Центральної Свропи (Швейцарія, Німеччина). У відібраних для дослідження тварин із високою вірогідністю підтверджено наявність ВХБ і його багаторічну циркуляцію серед цих тварин. Робиться висновок про важливу роль даного виду тварин як природного господаря вірусу хвороби Борна.

Також чутливі до борнавірусів гризуни, зокрема, миші, які заражаються цим вірусом i, можливо, передають інфекцію як одне одному, так і спадково (Okamoto et al., 2003). Останнє доведено експериментально за внутрішньоочеревинного зараження вагітних мишей штамом вірусу хвороби Борна. Дослідники встановили, що хронічна інфекція ВХБ може індукувати вертикальну передачу вірусу під час вагітності.

\section{Виявлення борнавірусів у біологічному матеріалі}

Сучасна наука має у своєму арсеналі різні методи та способи для виявлення різних патогенів у досліджуваному матеріалі. Особливо це стосується вірусів, адже для їх виявлення та ідентифікації потрібно витрачати набагато більше часу та ресурсів, ніж для інших патогенів (бактерій, грибів, найпростіших тощо). Крім того, тут необхідна висока точність та мінімум часу. Адже рання діагностика сприяє швидкому встановленню етіологічного фактора та дозволяє своєчасно вжити профілактичні заходи. У випадку дослідження збудників зоонозних інфекцій, особливо тих, що мають прихований перебіг, виникають певні труднощі у підборі матеріалу та адекватних методів лабораторної діагностики. За більшості вірусних інфекцій основна увага відводиться експрес-методам діагностики, серологічним і молекулярно-біологічним методам.

Із метою виявлення борнавірусів для дослідження найчастіше беруть зразки крові тварин (Dacheux et al., 2014; Dürrwald, 2014; Lutz et al., 2015; Kuhn et al., 2015) або людини (Amsterdam et al., 1985; Takahashi et al., 1997; Patti et al., 2008; 
Flower et al., 2008; Barrantes et al., 2012; Zhang et al., 2014; Liu et al., 2015; Mazaheri-Tehrani et al., 2014; Zaliunaite et al., 2016). Також досліджуваним матеріалом може бути спинномозкова рідина (Rott et al., 1991; de la Torre et al., 1996; Zhang et al., 2014), біоптати головного мозку (Kinnunen et al., 2013; Hoffmann et al., 2015; Lutz et al., 2015) як тварин, так і людини. Крім цього, від тварин можна брати інший матеріал - пір'я та яйця птахів (Dittrich et al., 1989; Berg et al., 2001; Staeheli et al., 2010; Kerski et al., 2012), біоптати вилочкової залози та кісткового мозку (Carbone, 2001; Bode and Ludwig, 2003), випорожнення та сечу комахоїдних кажанів (Dacheux et al., 2014), гризунів (Lutz et al., 2015), а також мазки з ротоглотки, органи загиблих тварин та інший матеріал.

Основні методи дослідження матеріалу від тварин із метою виявлення власне борнавірусів можуть бути: електронномікроскопічний (Richt et al., 1997; Ludwig, Bode, 2000; Kinnunen et al., 2013; Kuhn et al., 2015) із виявленням вірусних включень у заражених клітинах головного мозку (de la Torre et al., 1996; Ikuta et al., 2002; Staeheli et al., 2010; Matsumoto et al., 2012; Hoffmann et al., 2015), гістологічний або імуногістологічний (de la Torre et al., 1996; Richt et al., 1997; Dürrwald et al., 2014; Bourg et al., 2016; Wensman et al., 2016) чи вірусологічний із зараженням чутливих ліній клітин, таких як Vero, MDCK, нервова та ниркова тканина ембріона людини, ембріональні гліальні клітини кролика, гліома щурів (Lundgren et al., 1995; Ludwig and Bode, 2000; Carbone, 2001; Bode and Ludwig, 2003; Kinnunen et al., 2013). Інший важливий метод для встановлення борнавірусів у матеріалі - визначення наявності їх РНК із використанням ПЛР (de la Torre et al., 1996; Takahashi et al., 1997; Iwahashi et al., 1997; Planz et al., 1999; Carbone, 2001; Nakamura et al., 2000; Brnic et al., 2011; Barrantes et al., 2012; Kinnunen et al., 2013; Dacheux et al., 2014; Bonnaud et al., 2015; Hoffmann et al., 2015; Liu et al., 2015).

Для серологічної діагностики 3 метою виявлення специфічних антитіл до борнавірусів чи їх антигенів у сироватці крові як у тварин, так і людини найчастіше використовують IФА (Amsterdam et al., 1985; Rott et al., 1985, 2001; Waltrip et al., 1995; Bode et al., 1996; Carbone, 2001; Hornig et al., 2012), імуноблотинг (Iwahashi et al., 1997; Carbone, 2001), вестернблот (Waltrip et al., 1995; Flower et al., 2008; Zhang et al., 2014), визначення концентрації циркулюючих імунних комплексів до BXБ (Bode and Ludwig, 2003; Donfrancesco et al., 2008; Patti et al., 2008; Scholbach and Bode, 2008; Mazaheri-Tehrani et al., 2014; Liu et al., 2015; Zaliunaite et al., 2016), PEMA (ELISA) (Carbone, 2001; Zhang et al., 2014), радіоімунний аналіз (Matsunaga et al., 2008).

\section{Значення борнавірусів у патології людини}

Питання про інфекційність вірусу Борна для тварин не залишає сумнівів. Його здатність викликати неврологічні та поведінкові розлади у свійських тварин (коні, вівці) також показана для інших видів хребетних тварин, у тому числі лабораторних (пацюки, миші) (Ikuta et al., 2002). Численні дослідження з вивчення його циркуляції серед диких і домашніх тварин, вплив на поведінкові реакції, порушення з боку сенсорних систем, зміну поведінки та інше з'являються чи не щороку (Kinnunen et al., 2013; Bonnaud et al., 2015; Kuhn et al., 2015; Lennartz et al., 2016).

Крім того, останніми роками з'являються відомості про наявність самого вірусу Борна чи антитіл до нього у крові людей, які страждають порушеннями психіки (шизофренія, біполярні розлади, тривожні розлади, синдром хронічної втоми, розсіяний склероз, бічний аміотрофічний склероз, недоумкуватість, гліобластома і навіть депресія). Серологічні та молекулярно-епідеміологічні дослідження показали, що ВХБ може інфікувати людей, викликаючи вказані нейропсихічні порушення. Перші дані про наявність антитіл у сироватці крові до вірусу Борна в людей описані ще у 1985-1999 pp.
Дослідження зразків сироватки крові 265 пацієнтів із депресією та 105 здорових волонтерів виявило вірусоспецифічні антитіла до ВХБ лише у хворих (12 пацієнтів) і у жодного здорового піддослідного (Amsterdam et al., 1985). Антитіла також виявляли за допомогою методу непрямої імунофлуоресценції в сироватці крові психіатричних пацієнтів (16 3 979 обстежених), що стало поштовхом для подальших досліджень роль ВХБ у патології людини (Rott et al., 1985). Згодом аналогічні антитіла виявлені в сироватці крові 4-7\% пацієнтів iз психічними розладами під час скринінгового обстеження понад 5000 хворих у Німеччині, США та Японії (Rott et al., 1991). Крім того, навність борнавірусу у цих пацієнтів дослідники підтвердили шляхом інокуляції спинномозкової рідини хворих у культуру клітин кроля.

Використання непрямої імунофлуоресценції та вестернблоту дозволило встановити наявність специфічних антитіл до білків ВХБ у хворих на шизофренію в США (Waltrip et al., 1995). Дослідження стосувалося 90 пацієнтів і контрольної групи, що складалася з 20 здорових добровольців. У 13 з 90 хворих (14,4\%) підтверджено наявність антитіл до борнавірусу, чого не спостерігали в контролі. Гістопатологічні зміни під час аутопсії мозку пацієнтів із психічними розладами, втратою пам'яті та депресією корелювали з наявністю антигенів та РНК борнавірусу в чотирьох із п'яти пацієнтів, що підтверджено імуноцитохімічно та за допомогою ПЛР (de la Torre et al., 1996).

Інфекційний борнавірус виділений також від пацієнтів психіатричних клінік у мононуклеарних клітинах периферичної крові (Bode et al., 1996). Дослідникам вдалося не лише показати наявність у 33 психічно хворих пацієнтів антитіл до ВХБ, а й виділити та ідентифікувати вірус, заразити ним експериментальних тварин. Генетичні та біологічні властивості вказаного борнавірусу схожі з тваринними, проте мають певні унікальні властивості в кожному дослідженому випадку. Іншими дослідженнями показано наявність антитіл у сироватці крові, що реагують зі специфічними антигенами ВХБ, у пацієнтів із нервово-психічними розладами (Richt et al., 1997). Проте автори пишуть, що не виявили ні РНК борнавірусу, ні його антигенів у цих пацієнтів, а саме захворювання, на їхню думку, спричинене опосередкованою Т-лімфоцитами імунною відповіддю.

Суттєве скринінгове дослідження серед 67 пацієнтів 3 шизофренією в Японії показало наявність антитіл до борнавірусу у 45\% обстежених (Iwahashi et al., 1997). Хоча дослідники не встановили епідеміологію збудника у даних хворих, вони припускають відсутність внутрішньолікарняного зараження, а також відсутність зв'язку між вірусом і віком пацієнтів, процедур переливання крові чи особливостями лікування. Окрім того, виявлено за допомогою ПЛР вірусну РНК борнавірусу та його антигени шляхом імуногістохімічного дослідження в мозковій тканині, яку отримали в результаті аутопсії від психічно хворих пацієнтів із шизофренією та здорових людей посмертно (Nakamura et al., 2000). У подальшому дослідники заразили гомогенатом мозкової тканини пацієнтів піщанок і щурів шляхом внутрішньомозкової ін'єкції, а також інфікували культуру клітин Vero для подальшої ідентифікації вірусу. Дослідникам удалося відтворити інфекцію та підтвердити гіпотезу стосовно ролі ВХБ у розвитку психічних захворювань людини.

Інші дослідження, проведені в Японії, стосувалися вивчення зразків сироватки крові 304 пацієнтів психіатричних клінік 3 різними розладами та 378 зразків від здорових донорів на предмет виявлення в них специфічних імуноглобулінів IgM та IgG до ВХБ за допомогою радіоімунного аналізу (Matsunaga et al., 2008). Специфічні антитіла (IgG) до ВХБ, виявлені в обох групах дослідження, були нижче середнього рівня та достовірно не відрізнялися між собою, а ось вміст IgM не зменшувався тривалий час. Останнє автори пояснюють можливою затримкою імунної відповіді до борнавірусу та, можливо, ширшим поширенням останнього серед населення, ніж передбачалося раніше. У працівників ферм із розведення коней у місті 
Саппоро (Японія) відсоток виявлення РНК ВХБ суттєво вищий, ніж по інших регіонах країни та відносно здорових донорів крові (Takahashi et al., 1997). Виявлення інфекції в людей при цьому тісно корелює 3 аналогічною ситуацією у хворих тварин, тому дослідники припускають можливість передачі борнавірусу горизонтально від інфікованих коней до людини під час тісних контактів.

Достатньо об'ємні експериментальні дослідження, проведені в Німеччині стосовно ролі борнавірусів у патології людини показали, що часто під час виявлення в клітинах крові (гранулоцити) пацієнтів із психічними розладами (шизофренія та депресія) РНК вірусу не супроводжується гуморальною та клітинною імунною відповіддю (Planz et al., 1999). При цьому дослідники не відкидають певного значення ВХБ у розвитку психічних захворювань людини, проте припускають, що наявність вірусу в організмі таких людей може супроводжуватися суттєвим імунодепресивним ефектом і загальним зниженням імунореактивності. На думку авторів дослідження, виявлення ними борнавірусу в клітинах периферичної крові може пояснити труднощі попередніх досліджень із виявлення інфекційного ВХБ в організмі хворих тварин і пацієнтів із психічними розладами, а подібності послідовностей виділених вірусів від тварин і людей можуть свідчити про спільність їх і необхідність подальших досліджень.

Один із можливих шляхів передачі багатьох вірусних інфекцій - трансмісивний. Тому дослідження, які стосуються наявності вірусу хвороби Борна у крові хворих і здорових людей, проводили неодноразово. Одне з таких масових досліджень, проведене в Австралії, стосувалося вивчення зразків крові не лише психічно хворих пацієнтів (290 проб від пацієнтів із депресією), а і здорових донорів (219 проб) та 214 вагітних жінок (Flower et al., 2008). В 11 психіатричних пацієнтів за допомогою ІФА, вестерн-блоту, РІФ підтверджено наявність вірусних антигенів у сироватці крові. Водночас серед вагітних підтверджено лише три позитивні результати та два позитивні результати у здорових донорів. Окремо обстежено групу пацієнтів, які мали багаторазові процедури переливання крові: зі 168 зразків у 21 випадку підтверджено наявність антигенів ВХБ. На думку дослідників, багаторазове переливання крові може бути одним із факторів можливого зараження борнавірусами. Тому вони пропонують проводити ретельніше обстеження донорської крові.

Інше важливе питання стосовно епідеміології борнавірусів серед людей - поширеність серед дитячого населення, адже це важливо 3 огляду того, що діти часто контактують із різними тваринами (домашніми чи свійськими), досить часто можуть заражатися зоонозними інфекціями (Scholbach and Bode, 2008). Iз приводу цього численні дослідження дітей провели різні групи дослідників в Італії (Donfrancesco et al., 2008; Patti et al., 2008; Scholbach and Bode, 2008). Вивчено зразки крові понад 2000 дітей із різних регіонів Італії, як здорових, так і 3 психічними розладами (біполярні розлади, депресія). У сироватці крові вивчали такі маркери інфекції як циркулюючі імунні комплекси та антитіла до основних білків борнавірусів (N (p40) i P (p24)) із використанням імуноферментного аналізу. Отримані різними групами дослідників результати свідчать, що майже у половини обстежених здорових пацієнтів наявні в сироватці крові маркери ВХБ. Водночас не виявлено істотної різниці аналогічних показників між психічно хворими дітьми та здоровими. Хоча автори не проводять чітких паралелей між борнавірусами, психічними розладами у дітей, а також дорослих, проте вони пропонують проводити подальші дослідження 3 метою з'ясування ролі борнавірусів у розвитку психічних захворювань у дитячому віці.

Також про можливу роль вірусу Борна у розвитку психоневротичних патологій у людини пишуть дослідники в останні роки. У період 2011-2013 рр. із симптомами енцефаліту померло троє селекціонерів білок. Вказані тварини також мали енцефаліти з аналогічними клінічними ознаками та загинули в досить короткий період (2-4 місяці) після появи клінічних симптомів. Застосування метагеномного підходу дослідження 3 використанням полімеразної ланцюгової реакції (ПЛР) дало змогу виявити наявність раніше невідомого борнавірусу у зразках головного мозку від цих трьох пацієнтів, який відповідав аналогічному вірусу від досліджуваних тварин із майже $80 \%$ ідентичністю (Hoffmann et al., 2015). Одними з можливих шляхів передачі вірусу від тварин до людини автори вказують укуси та подряпини від білок. Інші дослідження, проведені в декількох провінціях Китаю серед хворих на різні психоневротичні розлади та здорових пацієнтів із виявлення зразків РНК вірусу хвороби Борна в церебральній рідині (1 481 проба) та периферійній крові (1 679 проб) (Zhang et al., 2014), показали іiі наявність у значної кількості пацієнтів із вірусним енцефалітом $(6,7 \%)$, шизофренією $(9,9 \%)$ і навіть синдромом хронічної втоми (12,7\%). У багатьох обстежених пацієнтів виявлено антитіла до ВХБ при таких захворюваннях як розсіяний склероз $(25,0 \%)$ та хвороба Паркінсона $(22,7 \%)$. Це дослідження доводить наявність вірусу хвороби Борна серед населення декількох провінцій Китаю та показує значення цього вірусу у патології людини (при шизофренії, розсіяному склерозі та навіть хворобі Паркінсона).

Група дослідників із Китаю також виявила наявність ВХБ у пацієнтів із важкою депресією та психоневротичними розладами (Liu et al., 2015). Проведене ними скринінгове дослідження стосувалося визначення наявності середньомолекулярних циркулюючих імунних комплексів, РНК вірусу та специифічних антитіл у сироватці крові з 1529 проб. Із них 534 проби відібрано у хворих на депресивні стани, 615 проб взято від медичного персоналу, який контактував із цими хворими, та 380 проб - від практично здорових волонтерів. Рівень ЦІК у пацієнтів вірогідно перевищував аналогічний рівень у здорових людей (18,2\% проти $11,1 \%)$, а у медичного персоналу цей відсоток складав аж $21,8 \%$. Аналогічна тенденція спостерігалася також стосовно виявлення антитіл і РНК вірусу. Така поширеність ВХБ серед медичних працівників може свідчити про циркуляцію вірусу серед співробітників психіатричних клінік без розвитку в них симптомів захворювання, а подібність РНК вірусу у пацієнтів і медпрацівників може свідчити про високий ризик професійного зараження у процесі тривалого спілкування.

Вірус хвороби Борна спричинює імунопатологічні ураження центральної нервової системи (Т-клітинно-опосередкована цитотоксичність, надмірне виділення цитокінів у мікроглії, «Глутаміновий шторм» із надлишковим виділенням глутамату. Усі ці процеси призводять до загибелі нейронів та клітин глії у багатьох видів тварин. Проте виявити антитіла до нього у людини вкрай важко (антитіла виявляються лише в 0,5\% населення). Це може бути зумовлено низьким рівнем вірусемії у психічно хворих пацієнтів і здорових людей. Оскільки наявні дані свідчать про асоціацію $з$ цією вірусною інфекцією таких захворювань як біполярні розлади та шизофренія, проведене скринінгове дослідження 76 зразків від людей: 51 пацієнт із біполярним розладом і 25 здорових добровольців (Barrantes et al., 2012). У дев'яти пацієнтів із розладами результати позитивні для різних білків вірусу хвороби Борна (p24 і p40), у здорових донорів - негативні. Виявлено високий вміст аналогічних білків серед обстежених домашніх тварин (коні), у зв'язку з чим автори роблять висновок про значну можливість зв'язку захворювань у людини та вірусом хвороби Борна.

Інше дослідження стосовно поширеності інфекції, спричиненої вірусом хвороби Борна в людини, проведене на Близькому Сході (Іран) і спрямоване на виявлення специфічних антитіл, циркулюючих імунних комплексів і антигенів вірусу в сироватці крові пацієнтів із гострими психіатричними розладами та здорових осіб із використанням імуноферментного аналізу (Mazaheri-Tehrani et al., 2014). Вивчено 314 зразків (від 114 психіатричних пацієнтів, 69 донорів крові та 131 здорової людини). Середньомолекулярні циркулюючі імунні комплекси 
виявлено у третині (29,5\%) інтактних зразків: 27,5\% здорових людей і 33,3\% донорів. У психічно хворих концентрація аналогічних циркулюючих імунних комплексів вища $(40,4 \%)$, тісно корелювала 3 клінічними симптомами біполярних розладів. У жінок обох груп цей показник також вірогідно вищий. На думку дослідників, це може свідчити про високу поширеність субклінічних інфекцій хвороби Борна у людини в Ірані, а подальші дослідження повинні враховувати ризик розвитку хвороби у здорових носіїв, особливо жіночої статі.

Скринінгове дослідження наявності антигенів борнавірусів та циркулюючих імунних комплексів у пацієнтів психіатричних клінік і здорових донорів крові проведене в Литві з метою підтвердження чи спростування ролі ВХБ у розвитку психічних розладів (Zaliunaite et al., 2016). Кров узято у 106 пацієнтів із гострим психозом, які перебували на стаціонарному лікуванні, та 98 практично здорових донорів крові. Отримані результати показали, що циркулюючі імунні комплекси до ВХБ частіше виявляються у хворих (39,6\%), ніж у здорових людей $(22,4 \%)$, а вміст антигенних маркерів в обох групах практично не відрізнявся. Відповідно, робиться висновок про хронічну ВХБ-інфекцію у психічно хворих пацієнтів, що підтверджує, на думку авторів, попередні дослідження стосовно ролі борнавірусів у розвитку психічних розладів у людини.

Отже, практично більшість авторів пишуть про виявлення як антитіл до цього вірусу у сироватці крові, так і його РНК і антигенів у досліджуваних матеріалах від пацієнтів (кров, спинномозкова рідина, біоптати мозку), що мають певні психічні зрушення - шизофренію, депресію, синдром тривалої втоми, розсіяний склероз тощо. Хоча інфекційність вірусу хвороби Борна для людини ще чітко не з'ясована, описані випадки показують можливість його потрапляння в організм людини (можливо, від домашніх чи диких тварин) та вплив на її психічне здоров'я.

Одне 3 досить численних досліджень, спрямованих на 3'ясування зв'язку між психічними захворюваннями (шизофренія, афективні розлади) та вірусом хвороби Борна проведені в Туреччині Karakose et al. (2011). Обстежено 207 пацієнтів різного віку та статі із залишковою шизофренією, 137 практично здорових пацієнтів групи порівняння на наявність РНК вірусу хвороби Борна у периферичній крові з використанням ПЛР і специфічних антитіл (IgG) до антигенів ВХБ (p24 і p40) за допомогою РЕМА. Встановлено суттєву різницю $(\mathrm{P}<0,001)$ між обома групами обстежених по кількості антитіл у сироватці крові, проте не встановлено чітких відмінностей вмісту РНК вірусу. Також повідомляється про відсутність чіткого зв'язку між розвитком шизофренії та молекулярних методів дослідження $з$ використанням регресійного аналізу, тому пропонується проведення подальших досліджень, як клінічних, так і експериментальних, для встановлення ролі борнавірусів у розвитку шизофренії.

Дослідницька група 3 Інституту Роберта Коха (Берлін) проводила дослідження можливого впливу вірусу Борна на організм людини серед мешканців, які утримують вдома домашніх тварин (котів), займаються фермерством або полюванням (Lutz et al., 2015). Серед багатьох видів домашніх та свійських тварин виявлено наявність як РНК вірусу, так і антитіл до нього у сироватці крові (коні, вівці, страуси, коти та собаки). Зокрема, у домашніх котів спостерігаються чіткі клінічні ознаки захворювання, яке викликає ВХБ - негнійний менінгоенцефаліт, ураження нюхових нервів, хитка хода, атаксія, зміна поведінки. Проте у власників цих та інших тварин навіть після тривалого та тісного контакту не виявлено не лише жодних ознак захворювання, а і наявності вірусної РНК чи антитіл до ВХБ. Відповідно автори роблять висновок про відсутність суттєвого значення вірусу хвороби Борна в розвитку психічних захворювань людини.

Велике скринінгове дослідження проведене в США на предмет асоціації психічних захворювань 3 антитілами до вірусу хвороби Борна (Hornig et al., 2012; Horning, 2016): дослідили
396 зразків сироватки крові хворих на різні психічні розлади (шизофренія, біполярні розлади, депресія) віком 20-75 років і практично здорових людей. Всі досліджені зразки крові пацієнтів і здорових людей ретельно відібрано з урахуванням віку, статі, періоду захворювання та обстежено на РНК вірусу за допомогою ПЛР і специфічних антитіл за допомогою імуноферментного аналізу. Отримані результати, на думку авторів, переконливо доводять відсутність такої залежності між наявністю антитіл у сироватці крові до вірусу Борна та психічних розладів. Проте дослідники не відкидають можливості наявності вірусної РНК чи антитіл до вірусу у спинномозковій рідині деяких пацієнтів із психоневрологічними розладами, що потребує подальших досліджень.

Нещодавно отримані результати різних наукових досліджень, які показують ще одну важливу біологічну роль борнавірусів - інтеграція в геном хребетних тварин у ході еволюції (Belyi et al., 2010; Horie et al., 2010; Horie et al., 2013; Gilbert et al., 2014). Ці дослідження стосувалися вивчення послідовності ДНК різних видів хребетних тварин, у тому числі приматів, на предмет наявності в них ендогенних ретровірусів та інших елементів, які могли бути «вмонтованими» в геном у ході еволюції. Крім власне ретровірусів у геномі багатьох видів тварин присутні також геноми інших представників родин вірусів, зокрема, порядку Mononegavirales (Dürrwald et al., 2014; Temmam et al., 2014). Найчастіше це філовіруси (зокрема, вірус Ебола) та борнавіруси (вірус хвороби Борна). Одним із можливих механізмів реалізації цих ендогенних борнавірусів може бути їх роль у регуляції функцій клітини, іiі неконтрольованого розмноження (проліфераціі) та загибелі (апоптозі) (He et al., 2016). Адже саме борнавіруси мають унікальну здатність інтегруватися у процесі своєї реплікації в геном господаря, тому автори припускають набагато ширше коло природних господарів цих вірусів, a їх біологічне значення потребує подальшого вивчення.

\section{Висновки}

Як показав аналіз літературних даних, можна стверджувати суттєву роль борнавірусів у розвитку різних психічних і поведінкових зрушень у тварин (як диких, так і домашніх). Проте велика кількість суперечливих даних ще не дає чіткої відповіді про значення цього вірусу в патології людини. 3 одного боку - це чіткі дані про наявність РНК вірусу хвороби Борна й антитіл до нього у хворих із психоневротичними порушеннями. 3 іншого - у науковій літературі немає однозначного уявлення про інфекційність цього вірусу для людини.

Відсутні дані про можливість передачі вірусу від тварин до людини, а також від людини до людини. Це питання потребує подальших досліджень, зокрема, на території України. Крім цього, подальших досліджень потребує питання значення представників порядку Mononegavirales у функціонуванні геному хребетних тварин і людини, їх можливе значення в еволюції.

\section{References}

Afonso, C. L., Amarasinghe, G. K., Bányai, K., Bào, Y., Basler, C. F., Bavari, S., Bejerman, N., Blasdell, K. R., Briand, F. X., Briese, T., Bukreyev, A., Calisher, C. H., Chandran, K., Chéng, J., Clawson, A. N., Collins, P. L., Dietzgen, R. G., Dolnik, O., Domier, L. L., Dürrwald, R., Dye, J. M., Easton, A. J., Ebihara, H., Farkas, S. L., Freitas-Astúa, J., Formenty, P., Fouchier, R. A., Fù, Y., Ghedin, E., Goodin, M. M., Hewson, R., Horie, M., Hyndman, T. H., Jiang, D., Kitajima, E. W., Kobinger, G. P., Kondo, H., Kurath, G., Lamb, R. A., Lenardon, S., Leroy, E. M., Li, C. X., Lin, X. D., Liú, L., Longdon, B., Marton, S., Maisner, A., Mühlberger, E., Netesov, S. V., Nowotny, N., Patterson, J. L., Payne, S. L., Paweska, J. T., Randall, R. E., Rima, B. K., Rota, P., Rubbenstroth, D., Schwemmle, M., Shi, M., Smither, S. J., Stenglein, M. D., Stone, D. M., Takada, A., Terregino, C., Tesh, R. B., Tian, J. H., Tomonaga, K., Tordo, N., Towner, J. S., Vasilakis, N., Verbeek, M., Volchkov, V. E., Wahl-Jensen, V., Walsh, J. A., Walker, P. J., Wang, D., Wang, L. F., Wetzel, T., Whitfield, A. E., Xiè, J. T., Yuen, K. Y., Zhang, 
Y.Z., \& Kuhn, J. H. (2016). Taxonomy of the order Mononegavirales: update 2016. Archives of Virology, 161(8), 2351-2360.

Amsterdam, J. D., Winokur, A., Dyson, W., Herzog, S., Gonzalez, F., Rott, R., \& Koprowski, H. (1985). Borna disease virus. A possible etiologic factor in human affective disorders? Archives of General Psychiatry, 42(11), 1093-1096.

Barrantes-Rodriguez, X., Silva, S., Macaya, G., \& Bonilla, J. A. (2012) Detection of borna virus disease by real-time RT-PCR in Costa Rican equines and humans. Archives of Clinical Microbiology, 3(1), 1-5.

Belyi, V. A., Levine, A. J., \& Skalka, A. M. (2010). Unexpected inheritance: Multiple integrations of ancient bornavirus and ebolavirus/marburgvirus sequences in vertebrate genomes. PLoS Pathogens, 6(7), e1001030.

Berg, M., Johansson, M., Montell, H., \& Berg, A.-L. (2001). Wild birds as a possible natural reservoir of Borna disease virus. Epidemiology and Infection, 127(1), 173-178

Bisyuk, I. Y. (2014). Suchasnyj stan i problemy kontrolju transkordonnyh emerdzhentnyh infekcij tvaryn v Ukrai'ni i sviti [Current status and problems of emergent control of transboundary animal infections in Ukraine and the world]. Veterynarna Medycyna Ukrai'ny, 220, 7-10 (in Ukrainian).

Bode, L., Dürrwald, R., Rantam, F. A., Ferszt, R., \& Ludwig, H. (1996) First isolates of infectious human Borna disease virus from patients with mood disorders. Molecular Psychiatry, 1(3), 200-212.

Bode, L., \& Ludwig, H. (2003). Borna disease virus infection, a human mental-health risk. Clinical Microbiology Reviews, 16(3), 534-545.

Bonnaud, E. M., Szelechowski, M., Betourne, A., Foret, C., Thouard, A., Gonzalez-Dunia, D., \& Malnou, C. E. (2015). Borna disease virus phosphoprotein modulates epigenetic signaling in neurons to control viral replication. Journal of Virology, 89(11), 5996-6008.

Bourg, M., Nobach, D., Herzog, S., Lange-Herbst, H., Nesseler, A., Hamann, H. P., Becker, S., Höper D., Hoffmann, B., Eickmann, M., \& Herden, C. (2016). Screening red foxes (Vulpes vulpes) for possible viral causes of encephalitis. Virology Journal, 13(1), 151.

Brnic, D., Stevanovic, V., Cochet, M., Agier, C., Richardson, J., MonteroMenei, C. N., Milhavet, O., Eloit, M., \& Coulpier, M. (2011). Borna disease virus infects human neural progenitor cells and impairs neurogenesis. Journal of Virology, 86(5), 2512-2522.

Caplazi, P., Waldvogel, A., Stitz, L., Braun, U., \& Ehrensperger, F. (1994) Borna disease in naturally infected cattle. Journal of Comparative Pathology, 111(1), 65-72

Carbone, K. M. (2001). Borna disease virus and human disease. Clinical Microbiology Reviews, 14(3), 513-527.

Christou, L. (2011). The global burden of bacterial and viral zoonotic infections. Clinical Microbiology and Infection, 17(3), 326-330.

Dacheux, L., Cervantes-Gonzalez, M., Guigon, G., Thiberge, J.-M., Vandenbogaert, M., Maufrais, C., Caro, V., \& Bourhy, H. (2014). A preliminary study of viral metagenomics of french bat species in contact with humans: identification of new mammalian viruses. PLoS ONE, 9(1), e87194.

de la Torre, J. C. (1994). Molecular biology of borna disease virus: Prototype of a new group of animal viruses. Journal of Virology, 68(12), 7669-7675.

de la Torre, J. C. (2002). Bornavirus and the Brain. The Journal of Infectious Diseases, 186(2), 241-247.

de la Torre, J. C., Gonzalez-Dunia, D., Cubitt, B., Mallory, M., MuellerLantzsch, N., Grässer, F. A., Hansen, L. A., \& Masliah, E. (1996) Detection of borna disease virus antigen and rna in human autopsy brain samples from neuropsychiatric patients. Virology, 223(2), 272-282.

Dittrich, W., Bode, L., Ludwig, H., Kao, M., \& Schneider, K. (1989). Learning deficiencies in borna disease virus-infected but clinically healthy rats. Biological Psychiatry, 26(8), 818-828.

Donfrancesco, R., Gregori, P., Vulcano, A., Candelori, E., Ronchetti, R., Miano, S., Pagani, J., Villa, M. P., \& Patti, A. M. (2008). Borna disease virus infection in children with psychiatric disorders. Acta Pathologica, Microbiologica et Immunologica Scandinavica, 116, 80-82.

Dürrwald, R., Kolodziejek, J., Weissenböck, H., \& Nowotny, N. (2014). The bicolored white-toothed shrew Crocidura leucodon (Hermann, 1780) is an indigenous host of mammalian Borna disease virus. PLoS ONE, 9(4), e93659.

Feschotte, C. (2010). Virology: Bornavirus enters the genome. Nature, 463(7277), 39-40.

Flower, R. L., Kamhieh, S., McLean, L., Bode, L., Ludwig, H., \& Ward, C. M. (2008). Human Borna disease virus infection in Australia: Serological markers of infection in multi-transfused patients. Acta Pathologica, Microbiologica et Immunologica Scandinavica, 116, 89-93.

Fotin, A. I., Panasenko, O. S., Panasenko, O. A., Pedan, V. A., \& Risovanij, V. I (2010). Analiz potencijnih nebezpek zarazhennja virusnimi infekcijami strausiv v Ukraini [Analysis of the potential risk of infection viral infection ostrich in Ukraine]. Visnyk Sums'kogo Nacional'nogo Agrarnogo Universytetutu. Serija Veterynarna Medycyna, 26, 126-131(in Ukrainian).
Gilbert, C., Meik, J. M., Dashevsky, D., Card, D. C., Castoe, T. A., \& Schaack, S. (2014). Endogenous hepadnaviruses, bornaviruses and circoviruses in snakes. Procedings of the Royal Society B. Biological Sciences, 281(1791), 1122-1131.

Gorohov, V. V., Uspenskij, A. V., Malysheva, N. S., Samofalova, N. A., Malysheva, E. V., Vlasov, E. A., \& Gladkih, K. A. (2012). Parazitarnye zoonozy: Sostojanie problemy [Parasitic zoonoses: Status of the problem]. Scientific Notes: The Online Academic Journal of Kursk State University, 21, 56-61 (in Russian).

Grynevych, O. I., Markovych, I. G., \& Markovych, I. F. (2012). Epidemiologichnyj nagljad za infekcijamy spil'nymy dlja ljudej ta tvaryn v Ukrai'ni [Epidemiological surveillance for infecious diseases common to humans and animals in Ukraine]. Veterynarna Medycyna, 96, 209-212 (in Ukrainian).

Grynevych, O. I., Markovych, I. G., \& Markovych, I. F. (2012). Rol' monitoryngu za infekcijamy, spil'nymy dlja ljudej i tvaryn, u zabezpechenni biobezpeky naselennja Ukrai'ny [The monitoring's role of infections common to humans and animals in the biosafety of the Ukrainian population]. Ukrai'ns'kyj Medychnyj Chasopys, 91, 111-114 (in Ukrainian).

Hasnatinov, M. A., \& Danchinova, G. A. (2011). Sovremennye sposoby monitoringa virusnyh patogenov i perspektivy sozdanija sistemy jekologo-jepidemiologicheskogo monitoringa virusov v okruzhajushhej srede [Modern approaches to the surveillance of viral pathogens and prospects of development of the eco-epidemiological network for survey of the viruses in the environment]. Bjulleten' VostochnoSibirskogo Nauchnogo Centra Sibirskogo Otdelenija Rossijskoj Akademii Medicinskih Nauk, 5, 195-198 (in Russian).

Hatalski, C. G., Lewis, A. J., \& Lipkin, W. I. (1997). Borna Disease Emerging Infectious Diseases, 3(2), 129-135.

He, P., Sun, L., Zhu, D., Zhang, H., Zhang, L., Guo, Y., Liu, S., Zhou, J., Xu, X., \& Xie, P. (2016). Knock-Down of endogenous bornavirus-like nucleoprotein 1 inhibits cell growth and induces fpoptosis in human oligodendroglia cells. International Journal of Molecular Sciences, 17(4), 435-448.

Hoffmann, B., Tappe, D., Höper, D., Herden, C., Boldt, A., Mawrin, C., Niederstraßer, J., Müller, T., Jenckel, M., van der Grinten, E., Lutter, C., Abendroth, B., Teifke, J.P., Cadar, D., Schmidt-Chanasit, J., Ulrich, R.G., \& Beer, M. (2015). A variegated squirrel bornavirus associated with fatal human encephalitis. The New England Journal of Medicine, $373,154-162$

Horie, M., Honda, T., Suzuki, Y., Kobayashi, Y., Daito, T., Oshida, T., Ikuta, K., Jern, P., Gojobori, T., Coffin, J. M., \& Tomonaga, K. (2010) Endogenous non-retroviral RNA virus elements in mammalian genomes. Nature, 463(7277), 84-87.

Horie, M., Kobayashi, Y., Suzuki, Y., \& Tomonaga, K. (2013). Comprehensive analysis of endogenous bornavirus-like elements in eukaryote genomes. Philosophical Transaction of the Royal Society B. Biological Sciences, 368(1626), 499-499.

Hornig, M. (2016). Borna disease virus. In: Reiss, C. S. (Ed.) Neurotropic viral infections. Springer International Publishing, p. 315-336.

Hornig, M., Briese, T., Licinio, J., Khabbaz, R. F., Altshuler, L. L., Potkin, S. G., Schwemmle, M., Siemetzki, U., Mintz, J., Honkavuori, K., Kraemer, H. C., Egan, M. F., Whybrow, P. C., Bunney, W. E., \& Lipkin, W. I. (2012). Absence of evidence for bornavirus infection in schizophrenia, bipolar disorder and major depressive disorder. Molecular Psychiatry, 17, 486-493.

Hornig, M., Briese, T., \& Lipkin, W. I. (2003). Borna disease virus. Journal of NeuroVirology, 9(2), 259-273.

Ikuta, K., Ibrahim, M. S., Kobayashi, T., \& Tomonaga, K. (2002). Born disease virus and infection in humans. Frontiers in Bioscience, 7, 470-495.

Iwahashi, K., Watanabe, M., Nakamura, K., Suwaki, H., Nakaya, T., Nakamura, Y., Takahashi, H., \& Ikuta, K. (1997). Clinical investigation of the relationship between Borna disease virus (BDV) infection and schizophrenia in 67 patients in Japan. Acta Psychiatrica Scandinavica, $96(6), 412-415$.

Kalinina, O. S. (2014). Suchasna klasyfikacija i nomenklatura virusiv hrebetnyh [Modern classification and nomenclature of viruses in vertebrates]. Naukovy] Visnyk L'vivs'kogo Nacional'nogo Universytetu Veterynarnoi' Medycyny ta Biotehnologij im. S. Z. G'zhyc'kogo, 16(3), 125-130 (in Ukrainian).

Karakose, A. R., Yuksel, P., Turan, N., Ziver, T., Saribaş, S., Alpay, N., \& Kocazeybek, B. (2011). Does Borna disease virus (BDV) have a role in the etiopathogenesis of schizophrenia? African Journal of Microbiology Research, 5(9), 1062-1069.

Kerski, A., De Kloet, A. H., \& De Kloet, S. R. (2012). Vertical transmission of avian bornavirus in Psittaciformes: Avian bornavirus RNA and antiavian bornavirus antibodies in eggs, embryos, and hatchlings obtained from infected sun conures (Aratinga solstitialis). Avian Diseases, 56(3), $471-478$ 
Kinnunen, P. M., Palva, A., Vaheri, A., \& Vapalahti, O. (2013). Epidemiology and host spectrum of Borna disease virus infections. Journal of General Virology, 94, 247-262.

Kuhn, J. H., Dürrwald, R., Bao, Y., Briese, T., Carbone, K., Clawson, A. N., deRisi, J. L., Garten, W., Jahrling, P. B., Kolodziejek, J., Rubbenstroth, D., Schwemmle, M., Stenglein, M., Tomonaga, K., Weissenböck, H., \& Nowotny, N. (2015). Taxonomic reorganization of the family Bornaviridae. Archives of Virology, 160(2), 621-632.

Lennartz, F., Bayer, K., Czerwonka, N., Lu, Y., Kehr, K., Hirz, M., Steinmetzer, T., Garten, W., \& Herden, C. (2016). Surface glycoprotein of Borna disease virus mediates virus spread from cell to cell. Cellular Microbiology, 18(3), 340-354.

Liu, S., Bode, L., Zhang, L., He, P., Huang, R., Sun, L., Chen, S., Zhang, H., Guo, Y., Zhou, J., Fu, Y., Zhu, D., \& Xie, P. (2015). GC-MS-based metabonomic profiling displayed differing effects of borna disease virus natural strain $\mathrm{Hu}$ $\mathrm{H} 1$ and laboratory strain V infection in rat cortical neurons. International Journal of Molecular Sciences, 16(8), 19347-19368.

Liu, X., Bode, L., Zhang, L., Wang, X., Liu, S., Zhang, L., Huang, R., Wang, M., Yang, L., Chen, S., Li, Q., Zhu, D., Ludwig, H., \& Xiecor, P. (2015). Health care professionals at risk of infection with Borna disease virus - evidence from a large hospital in China (Chongqing). Virology Journal, 12, 39.

Ludwig, H., \& Bode, L. (2000). Borna disease virus: New aspects on infection, disease, diagnosis and epidemiology. Revue Scientifique et Technique, 19(1), 259-288.

Lundgren, A.-L., Czech, G., Bode, L., \& Ludwig, H. (1993). Natural Borna disease in domestic animals others than horses and sheep. Zentralbl Veterinarmed B, 40(1-10), 298-303.

Lundgren, A.-L., Zimmermann, W., Bode, L., Czech, G., Gosztonyi, G., Lindberg, R., \& Ludwig, H. (1995). Staggering disease in cats: Isolation and characterization of the feline Borna disease virus. Journal of General Virology, 76, 2215-2222.

Lutz, H., Addie, D. D., Boucraut-Baralon, C., Egberink, H., Frymus, T., Gruffydd-Jones, T., Hartmann, K., Horzinek, M. C., Hosie, M. J., Lloret, A., Marsilio, F., Pennisi, M. G., Radford, A. D., Thiry, E., Truyen, U., \& Möstl, K. (2015). Borna disease virus infection in cats: ABCD guidelines on prevention and management. Journal of Feline Medicine and Surgery, 17, 614-616.

Makarov, V. V., 2011. Sinantropizacija, veterinarnaja jepidemiologija i zoonozy [Synanthropization, veterinary epidemiology and zoonoses]. Veterinarnaja Patologija, 4, 7-19 (in Russian).

Markovych, I. G., \& Grynevych, O. Y. (2013). Analiz epidemichnoi' sytuacii' shhodo zooantropnoziv v Ukrai'ni za 2011-2012 roky [Analysis of epidemic situation on zooanhtroponoses in Ukraine in 2011-2012]. Ukrai'na. Zdorov'ja Nacii', 26, 125-129 (in Ukrainian).

Matsumoto, Y., Hayashi, Y., Omori, H., Honda, T., Daito, T., Horie, M., Ikuta, K., Fujino, K., Nakamura, S., Schneider, U., Chase, G., Yoshimori, T., Schwemmle, M., \& Tomonaga, K. (2012). Bornavirus closely associates and segregates with host chromosomes to ensure persistent intranuclear infection. Cell Host and Microbe, 11(5), 492-503.

Matsunaga, H., Tanaka, S., Fukumori, A., Tomonaga, K., Ikuta, K., Amino, N., \& Takeda, M. (2008). Isotype analysis of human anti-Borna disease virus antibodies in Japanese psychiatric and general population. Journal of Clinical Virology, 43(3), 317-322.

Mazaheri-Tehrani, E., Maghsoudi, N., Shams, J., Soori, H., Atashi, H., Motamedi, F., Bode, L., \& Ludwig, H., 2014. Borna disease virus (BDV) infection in psychiatric patients and healthy controls in Iran. Virology Journal, 11, 161.

Nakamura, Y., Takahashi, H., Shoya, Y., Nakaya, T., Watanabe, M., Tomonaga, K., Iwahashi, K., Ameno, K., Momiyama, N., Taniyama, H., Sata, T., Kurata, T., de la Torre, J. C., \& Ikuta, K. (2000). Isolation of Borna disease virus from human brain tissue. Journal of Virology, 74(10), 4601-4611.

Okamoto, M., Hagiwara, K., Kamitani, W., Sako, T., Hirayama, K., Kirisawa, R., Tsuji, M., Ishihara, C., Iwai, H., Kobayashi, T., Tomonaga, K., Ikuta, K., \& Taniyama, H. (2003). Experimental vertical transmission of Borna disease virus in the mouse. Archives of Virology, 148(8), 1557-1568.

Patti, A. M., Vulcano, A., Candelori, E., Ludwig, H., \& Bode, L. (2008). Borna disease virus infection in the population of Latium (Italy). Acta Pathologica, Microbiologica et Immunologica Scandinavica, 116(124), 74-76.
Patti, A. M., Vulcano, A., Candelori, E., \& Travali, S. (2008). Serological evidence for Borna disease virus infection in children, cats and horses in Sicily (Italy). Acta Pathologica, Microbiologica et Immunologica Scandinavica, 116(124), 77-79.

Planz, O., Rentzsch, C., Batra, A., Batra, A., Winkler, T., Büttner, M., Rziha, H.J., \& Stitz, L. (1999). Pathogenesis of Borna disease virus: Granulocyte fractions of psychiatric patients harbor infectious virus in the absence of antiviral antibodies. Journal of Virology, 73(8), 6251-6256.

Richt, J. A., Pfeuffer, I., Christ, M., Frese, K., Bechter, K., \& Herzog, S. (1997). Borna disease virus infection in animals and humans. Emerging Infectious Diseases, 3(3), 343-352.

Richt, J. A., \& Rott, R. (2001). Borna disease virus: A mystery as an emerging zoonotic pathogen. The Veterenary Journal, 161(1), 2440.

Rosenberg, R. (2015). Detecting the emergence of novel, zoonotic viruses pathogenic to humans. Cellular and Molecular Life Sciences, 72(6), 1115-1125.

Rott, R., Herzog, S., Bechter, K., \& Frese, K. (1991). Borna disease, a possible hazard for man? Archives of Virology, 118(3-4), 143-149.

Rott, R., Herzog, S., Fleischer, B., Winokur, A., Amsterdam, J., Dyson, W., \& Koprowski, H. (1985). Detection of serum antibodies to Borna disease virus in patients with psychiatric disorders. Science, 228(4700), 755-756.

Scholbach, T., \& Bode, L. (2008). Borna disease virus infection in young children. Acta Pathologica, Microbiologica et Immunologica Scandinavica, 116(124), 83-88.

Sidorchuk, A. A. (2012). Sovremennye predstavlenija o zoonozah [Modern conceptions of zoonoses]. Sel's'kohozjajstvennye Zhivotnye, 4, 6-7 (in Russian).

Staeheli, P., Rinder, M., \& Kaspers, B. (2010). Avian bornavirus associated with fatal disease in psittacine birds. Journal of Virology, 84(13), 6269-6275.

Staeheli, P., Sauder, C., Hausmann, J., Ehrensperger, F., \& Schwemmle, M. (2000). Epidemiology of Borna disease virus. Journal of General Virology, 81, 2123-2135.

Stegnij, B. T., Gerilovych, A. P., Bisjuk, I. J., Moroz, D. A., \& Mandryga, M. S. (2014). Epizootychnyj monitoryng, prognozuvannja, reaguvannja pry transmisyvnyh hvorobah tvaryn i naukovyj suprovid problemy $\mathrm{v}$ Ukrai'ni [International experience monitoring, forecasting, response in vector-borne diseases of animals and scientific support problems in Ukraine]. Veterynarna Medycyna, 98, 5-11 (in Ukrainian).

Stitz, L., Krey, H., \& Ludwig, H. (1980). Borna disease in rhesus monkeys as a model for uveo-cerebral symptoms. Journal of Medical Virology, 6(4), 333-340.

Takahashi, H., Nakaya, T., Nakamura, Y., Asahi, S., Onishi, Y., Ikebuchi, K., Takahashi, T. A., Katoh, T., Sekiguchi, S., Takazawa, M., Tanaka, H., \& Ikuta, K. (1997). Higher prevalence of Borna disease virus infection in blood donors living near thoroughbred horse farms. Journal of Medical Virology, 52(3), 330-335.

Temmam, S., Davoust, B., Berenger, J.-M., Raoult, D., \& Desnues, C. (2014). Viral metagenomics on animals as a tool for the detection of zoonoses prior to human infection? International Journal of Molecular Sciences, 15(6), 10377-10397.

Tizard, I., Ball, J., Stoica, G., \& Payne, S. (2016). The pathogenesis of bornaviral diseases in mammals. Animal Health Research Reviews, $17(2), 92-109$.

Waltrip, R. W., Buchanan, R. W., Summerfelt, A., Breier, A., Carpenter, W. T. Jr., Bryant, N. L., Rubin, S. A., \& Carbone, K. M. (1995). Borna disease virus and schizophrenia. Psychiatry Research, 56(1), 33-44.

Wang, L.-F., \& Crameri, G. (2014). Emerging zoonotic viral diseases. Revue Scientifique et Technique, 33(2), 569-581.

Wensman, J. J., Leuchowius, K. J., Yan, J., Berg, A. L., Bode, L., Ludwig, H., \& Berg, M. (2016). Visualization of Borna disease virus protein interactions with host proteins using in situ proximity ligation assay. British Journal of Virology, 3(1), 11-23.

Zaliunaite, V., Steibliene, V., Bode, L., Podlipskyte, A., Bunevicius, R., \& Ludwig, H. (2016). Primary psychosis and Borna disease virus infection in Lithuania: A case control study. BMC Psychiatry, 16(1), 369-377.

Zhang, L., Xu, M.-M., Zeng, L., Liu, S., Liu, X., Wang, X., Li, D., Huang, R.Z., \& Zhao, L.-B. (2014). Evidence for Borna disease virus infection in neuropsychiatric patients in three western China provinces. European Journal of Clinical Microbiology and Infectious Diseases, 33(4), 621-627. 